\title{
PERAN KESELAMATAN DNA DALAM BUDAYA KESELAMATAN KEBERLANJUTAN UNTUK MENGURANGI KECELAKAAN DI DAERAH KERJA
}

\author{
Edison Sihombing ${ }^{*}$, Jaja Sukmana*, Dicky Tri Jatmiko*, Nazly Kurniawan* \\ ${ }^{1}$ PRSG-BATAN Serpong, Indonesia \\ edison@batan.go.id
}

Diterima: 14 April 2021, diperbaiki : 27 April 2021, disetujui : 4 Mei 2021

\begin{abstract}
ABSTRAK
PERAN KESELAMATAN DNA DALAM BUDAYA KESELAMATAN BERKELANJUTAN UNTUK MENGURANGI KECELAKAAN DI DAERAH KERJA. Faktor keselamatan kerja di Perusahaan sangat terkait dengan kinerja dari pekerjanya. Pelaksanaan Keselamatan dan Kesehatan Kerja (K3) merupakan salah satu upaya dalam menciptakan tempat kerja yang aman, sehat, dan bebas dari pencemaran lingkungan untuk mengurangi dan atau bebas dari kecelakaan kerja. Upaya untuk mencegah, mengurangi, dan mengendalikan bahaya di tempat kerja perlu dilakukan secara berkesinambungan berupa unsafe behaviour yang berasal dari sifat bawaan seseorang dalam membentuk sikap dan perilaku selamat, yaitu keselamatan DNA. Tujuan penyajian makalah ini adalah mendeskripsikan alur peran dan fungsi keselamatan DNA dalam membangun organisasi budaya keselamatan yang lebih efektif. Dalam penulisan makalah ini dilakukan suatu tahapan metode ilmiah agar dapat dilaksanakan sesuai dengan yang diharapkan. Adapun penelitian akan menitik beratkan pada peran keselamatan DNA pada aspek sistem manajemen keselamatan dan budaya keselamatan secara holistik. Keselamatan DNA adalah proses peningkatan pengetahuan tentang keselamatan yang akan membangun karakter individu dalam pelaksanaan BBS dalam penerapan budaya keselamatan. Karakteristik Safety Leadership dalam budaya keselamatan akan mendorong perubahan budaya keselamatan yang signifikan pada individu di semua fase penguatan budaya keselamatan organisiasi, tanpa melihat apakah organisasi sudah lama atau baru. Keselamatan DNA dapat dikategorikan sebagai katalis yang kuat untuk meningkatkan kinerja individu dan mendewasakan budaya keselamatan organisasi. Termasuk dengan komitmen enam cara untuk memastikan tempat kerja aman dan percepatan budaya keselamatan, yaitu menjadikan keselamatan sesuatu yang menyenangkan.
\end{abstract}

Kata kunci: Safety DNA, Budaya Keselamatan, Kecelakaan Kerja.

\section{ABSTRACT}

THE ROLE OF DNA SAFETY IN SUSTAINABLE A SAFETY CULTURE TO REDUCE ACCIDENTS IN WORKING AREAS. The work safety factor in the Company is closely related to employee performance. The implementation of Occupational Safety and Health (OSH) is an effort to create a work place that is safe, healthy, and free from environmental pollution to reduce and / or be free from work accidents. Efforts to prevent, reduce and control hazards in the workplace need to be carried out continuously in the form of unsafe behavior that comes from one's innate nature in shaping safe attitudes and behaviors, namely DNA safety. The purpose of presenting this paper is to describe the flow of the role of Safety \& Task DNA in building a more effective safety culture organization. In writing this paper, a scientific method is carried out so that it can be implemented as expected. The research will focus on the role of DNA safety in the aspects of safety management systems and safety culture holistically. DNA safety is a process of increasing knowledge about safety that will build individual character in the implementation of BBS in the application of safety culture. The characteristics of Safety Leadership in safety culture will encourage significant safety culture changes in individuals at all 
phases of strengthening the organizational safety culture, regardless of whether the organization is old or new. DNA safety can be categorized as a powerful catalyst for enhancing individual performance and maturing an organization's safety culture. This includes a commitment to six ways to ensure a safe workplace and the acceleration of a safety culture, namely to make safety something fun.

Keywords: Safety DNA, Safety Culture, Work Accidents.

\section{PENDAHULUAN}

Keselamatan kerja telah menjadi perhatian di kalangan pemerintah dan bisnis. Faktor keselamatan kerja menjadi penting karena sangat terkait dengan kinerja pekerja dan kinerja perusahaan. Kecukupan fasilitas keselamatan kerja memperkecil kemungkinan terjadinya kecelakaan kerja. Pelaksanaan Keselamatan dan Kesehatan Kerja (K3) ${ }^{[1]}$ adalah salah satu bentuk upaya menciptakan tempat kerja yang aman, sehat, dan bebas dari pencemaran lingkungan untuk mengurangi dan atau bebas dari kecelakaan kerja serta penyakit akibat kerja sehingga dapat meningkatkan efisiensi dan produktivitas kerja. Kecelakaan kerja adalah suatu kejadian yang tidak dikehendaki dan awalnya tidak diduga yang dapat menimbulkan korban manusia dan atau harta benda tentunya hal ini dapat mengakibatkan kerugian jiwa serta kerusakan harta benda[2].

Penelitian dan upaya untuk mencegah, mengurangi dan mengendalikan bahaya yang dapat menimbulkan kecelakan di tempat kerja selalu dilakukan secara berkesinambungan. Para ahli keselamatan maupun praktisi sepakat bahwa faktor penyebab kecelakaan sebesar $80 \%$ disebabkan faktor manusia. Faktor ini terbagi atas 30\% individu dan $50 \%$ organisasi. Sampai saat ini sudah banyak upaya para ahli mengembangkan cara untuk mengurangi kecelakaan di tempat kerja, hal ini juga berkembang bahwa kecelakaan akan berdampak pada tingkat kepercayaan terhadap aspek bisnis organisasi serta tingkat kepercayaan masyarakat secara umum. Beberapa metode sistem manajemen keselamatan dan faktor budaya yang saat ini digunakan organisasi dalam hal mengendalikan bahaya untuk mengurangi kecelakaan di tempat kerja, yaitu:

$$
\begin{aligned}
& \text { - Identifikasi bahaya dan } \\
& \text { pengendalian risiko (Hazard } \\
& \text { Identification, Risk Assessment } \\
& \text { and Determining, HIRADC) } \\
& \text { - Sistem manajemen keselamatan } \\
& \text { dan kesehatan kerja (SMK3) } \\
& \text { - } \quad \text { Iklim keselamatan } \\
& \text { - Behaviour Based Safety (BBS) } \\
& \text { - Budaya Keselamatan. }
\end{aligned}
$$

Mengapa setelah pengetahuan pada metode di atas orang masih bertindak tidak aman?. Pada dasarnya tidak ada pekerja yang bekerja merencanakan untuk melukai diri sendiri atau membuat lingkungan kerja tidak selamat, walaupun kenyataannya insiden masih terjadi. Dalam istilah medis, DNA adalah asam nukleotida yang merupakan rangkaian molekul penentu bentuk dan sifat semua mahluk hidup. Berdasarkan defenisi ini, maka praktisi keselamatan mencoba melakukan eksplorasi sifat tidak selamat melalui keselamatan DNA (Safety DNA). Dalam pendekataan ini, bahwa Safety DNA terbentuk dari sifat khas bawaan yang diturunkan dan dapat juga dibentuk melalui pengetahuan. Dengan pengetahuan yang terbentuk dalam Safety DNA maka Safety Task (perilaku yang terlihat) akan membentuk sikap dan perilaku selamat yang kuat $[3],[4],[5]$. 
Pendekatan model Safety DNA dan Safety Task akan mengukur tingkatan perilaku selamat yang ada pada seseorang apakah terbentuk dari sifat khas melalui bawaan atau dibentuk oleh ilmu pengetahuan sehingga menjadikannya suatu karakter khas bersifat selamat. $\mathrm{Hal}$ ini berproses begaimana otak mengolah informasi, pemikiran dan kepercayaan serta mengolah faktor eksternal seperti lingkungan kerja dan iklim sosial yang dapat membuat kondisi pekerja dan lingkungan tidak aman. Melalui pendekatan Safety DNA dan Safety TASK memungkinkan organisasi membangun perubahan yang lebih efektif, melalui program spesifik kebutuhan manajemen dan personil dengan cara yang lebih holistik tentang pemahaman perilaku yang mendorong individu bertingkah laku selamat[6],[7].

Pada makalah ini, penulis akan mendiskripsikan alur peran Safety DNA dan Task DNA untuk meningkatkan pelaksanaan BBS sehingga dapat memberikan internalisasi yang kuat di dalam pelaksanaan percepatan budaya keselamatan kepada pekerja yang memiliki Safety DNA sangat baik.

\section{PENDEKATAN TEORI}

Menurut Ridley, 2008[8], penyebab terjadinya kecelakaan kerja adalah sebagai berikut:

1. Situasi kerja, meliputi: Pengendalian manajemen yang kurang, standar kerja yang minim, tidak memenuhi standar, dan perlengkapan yang gagal atau tempat kerja yang tidak mencukupi.

2. Kesalahan orang, meliputi: Keterampilan dan pengetahuan yang minim, masalah fisik atau mental, motivasi yang minim atau salah penempatan, perhatian yang kurang.

3. Tindakan tidak aman, meliputi: Tidak mengikuti metode kerja yang telah disetujui, mengambil jalan pintas, menyingkirkan atau tidak menggunakan perlengkapan keselamatan kerja.

4. Kecelakaan, meliputi: kejadian yang tidak terduga, akibat kontak dengan mesin atau listrik yang berbahaya, terjatuh, dan terhantam mesin atau material yang jatuh dan sebagainya.

Safety DNA mengacu pada faktor psikologis yang secara konsisten terkait dengan hasil keselamatan pribadi (misalnya: insiden, cidera). Faktor-faktor ini terdiri dari ciri-ciri kepribadian, nilai, kemampuan, dan kepercayaan yang semuanya memprediksi kemungkinan cedera, dan setiap orang memiliki level dan kombinasi yang berbeda dari karakteristik ini. Akibatnya, setiap orang memiliki profil Safety DNA yang unik, membuat mereka lebih atau kurang rentan terhadap risiko di sekitar mereka.

Pendekatan model keselamatan DNA dan Safety Task akan mengukur tingkatan perilaku selamat yang ada pada seseorang apakah terbentuk dari sifat khas melalui bawaan atau dibentuk oleh ilmu pengetahuan yang menjadikannya suatu karakter khas bersifat selamat. $\mathrm{Hal}$ ini berproses bagaimana otak mengolah informasi, pemikiran dan kepercayaan serta faktor eksternal seperti lingkungan kerja dan iklim sosial dapat membuat kondisi pekerja dan lingkungan tidak aman ${ }^{[9]}$ seperti terlihat pada Gambar 1 di bawah ini. 


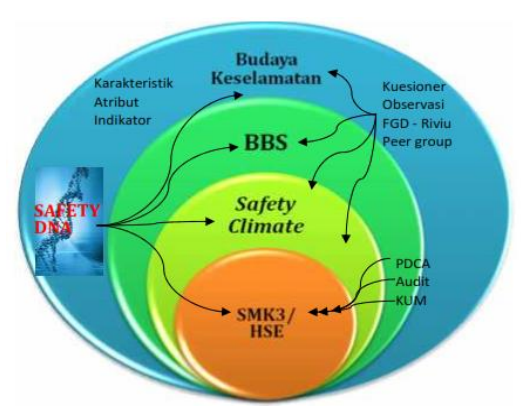

Gambar 1. Peran pengukuran keselamatan DNA dalam penguatan budaya keselamatan[10]

Individu sebagai faktor penyebab kecelakaan seringkali disebut sebagai "Human Error" dan sering disalah-artikan karena selalu dituduhkan sebagai penyebab terjadinya kecelakaan. Menurut Geller (2001), perilaku mengacu pada tingkah laku atau tindakan individu yang dapat diamati oleh orang lain [10]. Dengan kata lain, perilaku adalah apa yang seseorang katakan atau lakukan yang merupakan hasil dari pikirannya, perasaannya, atau diyakininya. Perilaku manusia menurut Dolores dan Johnson, 2005 (dalam Anggraini, 2011) adalah sekumpulan perilaku yang dimiliki oleh manusia dan dipengaruhi oleh adat, sikap, emosi, nilai, etika, kekuasaan, persuasi, dan atau genetika[11]. Skinner, merumuskan bahwa perilaku merupakan hasil hubungan antara perangsang (stimulus) dan tanggapan atau respon[12]. Oleh karena perilaku ini terjadi melalui proses adanya stimulus terhadap organisme, dan kemudian organisme tersebut merespon, maka teori Skinner ini disebut dengan teori "S-O-R" atau "Stimulus-Organisme-Respons".

Dari definisi di atas dapat dilihat bahwa perilaku berkaitan dengan faktor internal seperti pikiran dan emosi serta adat atau budaya, karena itulah ada istilah iklim keselamatan. Selain itu juga dapat dilihat bahwa salah satu faktor internal yakni pengetahuan sangat berpengaruh terhadap perilaku manusia, karena itu ada program safety awareness untuk meningkatkan kesadaran dan pengetahuan manusia mengenai keselamatan. Selain itu dapat dilihat bahwa perilaku berhubungan dengan faktor eksternal dan stimulus, oleh karena itu program-program yang dapat memberikan stimulus terhadap perilaku pekerja seperti individu, observasi, bahkan reward dan punishment itu memang harus diterapkan.

Faktor penentu perilaku terbagi atas 2 bagian yakni: (a) faktor internal, yaitu karakteristik orang yang bersangkutan yang bersifat bawaan dan berfungsi untuk mengolah rangsangan dari luar, misalnya tingkat pengetahuan, kecerdasan, persepsi, emosi, motivasi, jenis kelamin, dan sebagainya; dan (b) faktor eksternal, meliputi lingkungan sekitar, baik fisik maupun non-fisik, seperti iklim, manusia, sosial, budaya, ekonomi, politik, kebudayaan dan sebagainya. Faktor lingkungan ini sering merupakan faktor yang dominan mewarnai perilaku seseorang.

Heinrich: merasa bahwa tindakan yang tidak aman dan kondisi yang tidak aman adalah faktor utama dalam mencegah insiden, dan faktor penyebab termudah untuk memperbaiki, sebuah proses terkenal dengan teori Domino[13]. Ada empat alasan mengapa orang melakukan tindakan tidak aman "sikap yang tidak pantas, kurangnya pengetahuan atau keterampilan, ketidakcocokan fisik, dan lingkungan mekanik atau fisik yang tidak tepat. Dia kemudian melanjutkan untuk membagi kategori-kategori ini menjadi penyebab "langsung" dan "mendasar". Sebagai contoh, katanya, seorang pekerja yang melakukan tindakan tidak aman dapat melakukannya karena dia tidak yakin bahwa tindakan pencegahan yang tepat diperlukan, dan karena pengawasan 
yang tidak memadai. Kombinasi berbagai penyebab ini, katanya, menciptakan rantai peristiwa yang sistematis yang mengarah pada kecelakaan sperti terlihat pada Gambar 2 di bawah ini.

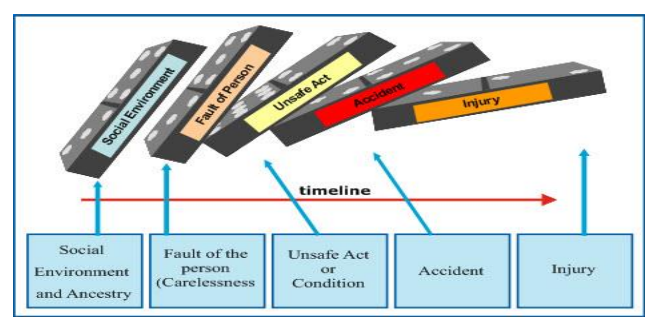

Gambar 2. Rangkaian penyebab kecelakaan menurut teori Domino

\section{METODE PENELITIAN}

Pada kegiatan penelitian ini, diperlukan suatu tahapan metode ilmiah agar dapat dilaksanakan sesuai dengan yang diharapkan. Adapun penelitian akan menitik beratkan pada peran Safety DNA pada aspek sistem manajemen keselamatan dan budaya keselamatan secara holistik, penulis berupaya memasukkan perannya secara deskripsi dengan harapan mudah diikuti dan mudah diterapkan. Mengingat belum banyaknya Pustaka dan best practice tentang Safety DNA, maka penulis mencoba melakukan pendekatan melalui safety climate, BBS, literature DuPont yang sudah mulai menerapkan keselamatan DNA untuk penguatan organisasi seperti Gambar 3 di bawah ini.

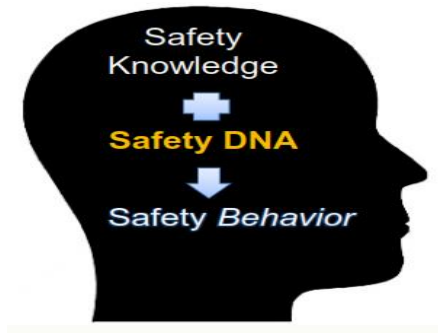

Gambar 3. Model proses pengembangan keselamatan ${ }^{[4]}$

budaya

\section{HASIL DAN PEMBAHASAN}

Jurnal Unhas[14]: hasil survey terhadap responden di perusahaan percetakan, bahwa jumlah responden yang pernah mengalami kecelakaan adalah 106 responden atau 72,6\%. Diketahui bahwa ruang kerja merupakan tempat yang paling dominan menjadi lokasi kecelakaan yaitu di ruang kerja operator sebanyak 278 kejadian (95,9\%). Berdasarkan hasil penelitian yang telah dilakukan, maka diperoleh data mengenai umur dan jumlah kejadian kecelakaan kerja yang dialami. Diketahui bahwa pada kelompok umur 20-24 tahun, terdapat persentase responden tertinggi yaitu $27,4 \%$ dan kejadian kecelakaan tertinggi yaitu 39,3\%. Semakin tinggi jumlah responden yang mengalami kecelakaan, maka semakin tinggi pula jumlah kejadian kecelakaan kerja. Hasil penelitian ini menunjukkan terdapat $72,6 \%$ responden yang pernah mengalami kejadian kecelakaan kerja. Persentase tersebut lebih tinggi dibandingkan penelitian yang dilakukan Agbenorku et.al. (2016) ${ }^{[15]}$ pada pekerja percetakan di Ghana, ditemukan bahwa sebanyak $67 \%$ kecelakaan kerja yang mengakibatkan cedera. Demikian bahwa, setiap tempat kerja selalu mengandung berbagai potensi bahaya yang dapat mempengaruhi kesehatan semua tenaga kerja atau dapat 
menyebabkan timbulnya penyakit akibat kerja $^{[14]}$.

Dupont $\begin{array}{cc}\text { Berdasarkan } & \text { pengalaman } \\ \text { beningkatkan } & \end{array}$
keselamatan, merumuskan bahwa sifat BBS seseorang dapat ditingkatkan dengan mengakumulasi Safety DNA dan pengetahuan, seperti ilustrasi pada Gambar 3. Safety DNA akan berproses pada peningkatan pengetahuan tentang keselamatan yang akan membangun karakter individu dalam pelaksanaan BBS saat penerapan budaya keselamatan. Karakteristik Safety Leadership dalam budaya keselamatan akan mendorong perubahan budaya keselamatan yang signifikan pada individu di semua fase penguatan budaya keselamatan organisiasi, tanpa melihat apakah organisasi sudah lama atau baru. Safety DNA dapat dikategorikan sebagai katalis yang kuat untuk meningkatkan kinerja individu dan mendewasakan budaya keselamatan organisasi[16]. Program keselamatan berbasis perilaku dan metode lainnya untuk mengelola keselamatan di tempat kerja bergantung pada organisasi tanggapan dan keluaran perilaku. Pendekatan ini hanya sebagian dari gambar dan tidak mencerminkan alasan orang bertindak dengan aman atau tidak aman.

\section{Safety DNA sebagai katalis budaya keselamatan}

Internalisasi elemen Safety DNA dalam diri individu selalu tercermin dalam tindakan aman, menciptakan lingkungan aman serta penguatan prosedur dan sikap perilaku selamat (BBS). Pendekatan baru ini menawarkan model praktis perilaku manusia yang mencakup pertimbangan bagaimana otak memproses informasi, pemikiran dan kepercayaan serta pengaruh faktor eksternal seperti lingkungan kerja dan iklim sosial di lingkungan kerja tertentu (safety climate). Safety DNA, budaya memungkinkan pimpinan organisiasi membangun perubahan yang lebih efektif melalui perencanaan program spesifik kebutuhan sesuai kebutuhan organisasi, proses/teknologi maupun individu pada sistem manajemen keselamatan dan budaya kerja serta peran safety leadership dalam organisasi. Hal ini dapat kebutuhan terjadinya perbaikan berkelanjutan atau budaya keselamatan yang berkelanjutan,percepatan budaya keselamatan dalam mencapai tingkat maturity (kedewasaan) budaya keselamatan maupun istilah lain adalah mencapai kondisi organisasi berada "di atas ketentuan yang disyaratkan".

\section{Usulan untuk meminimalkan peluang kesalahan}

Berikut ini hasil kajian untuk meminimalkan peluang kesalahan, meningkatkan K3, serta membantu budaya kerja yang selamat bagi setiap individu yang bertanggung jawab atas sikap selamat perseorangan dalam bekerja, yaitu :

a) Proses kerja/operasi selamat menjadi tanggung jawab semua pekerja;(operasi selamat selalu berawal dari lingkungan aman dan perilaku selamat), serta setiap proses kerja harus memiliki HIRADC.

b) Kesetaraan keputusan manajemen dalam produksi/proses dengan operasi yang aman (membuat alur proses setiap produksi sejalan dengan proses yang aman, sesuai standar (SOP), keselamatan harus didahulukan dari produksi sesuai tingkatannya;

c) Sejajarkan pekerja dan proses; (proses operasi yang aman harus disesuaikan dengan kondisi rekayasa produksi).

d) Libatkan pekerja dan pertimbangkan usulannya (secara praktis keputusan pribadi pekerja harus mendukung kepentingan operasi yang aman, 
pekerja selalu mampu mengidentifikasi lingkungan kerja yang aman saat berproduksi).

e) Mengembangkan perilaku pelaksana dan manajemen; gaya supervisor dan tim keselamatan akan berpengaruh terhadap kinerja tim produksi, dengan mengetahui tupoksi masing masing.

Supervisor dan pengawas membantu pekerja dalam pelaksanaan proses produksi, sehingga tidak terlihat sebagai pencari kesalahan,

f) Meningkatkan perilaku aman pekerja; Membangun dan menegakkan perilaku yang tepat untuk mencapai operasi yang aman di seluruh organisasi., Melakukan perubahan pola pikir baru terhadap operasi yang aman melalui sikap operasi yang aman,

Pengukuran kinerja dengan membangun indikator kinerja kritis ke dalam sistem operasi manajemen dan gabungkan dengan alat pengukuran yang tepat yang memperkuat semua disiplin produksi dan langkah-langkah keselamatan yang lazim disuatu tempat sesuai SOP dan rekayasanya, mengetahui langkah pengendalian.

g) Melibatkan pemangku kepentingan; (menyelaraskan kepentingan manajemen dan proses produksi, pengadaan, keuangan untuk mencapai proses produksi yang aman).

\section{Upaya Memelihara Tempat Kerja yang Aman}

Menciptakan dan memelihara lingkungan kerja yang aman harus menjadi prioritas tinggi bagi organisasi. Berdasarkan Undang-undang Keselamatan dan Kesehatan Kerja (K3), pengusaha memiliki tanggung jawab untuk menciptakan dan memelihara tempat Organisasi perlu secara aktif membina dan mempromosikan budaya keselamatan yang kuat, sepanjang tahun, sehingga keselamatan menjadi bagian dari DNA perusahaan. Peningkatan budaya keselamatan dalam suatu organisasi harus memiliki komitmen yang berkelanjutan untuk komunikasi. Salah satu metode populer untuk mempromosikan kesadaran keselamatan adalah melalui tanda digital di tempat kerja, yang memanfaatkan komunikasi visual untuk mempromosikan pesan.

Berikut adalah enam cara untuk memastikan tempat kerja yang aman, yaitu:

1. Menghilangkan potensi bahaya.

Dalam menghilangkan potensi bahaya dilakukan dengan menjaga tempat kerja agar bebas dari bahaya fisik dan kimia yang sesuai dengan standar, aturan, dan peraturan OSHAS atau ISO. Menggunakan sistem sinyal digital untuk mengingatkan pekerja tentang mekanisme tubuh yang benar, keselamatan forklift, dukungan yang aman. Menggunakan APD yang diperlukan secara benar untuk menghindari slip, tersandung, dan jatuh. Mendorong pekerja untuk mengidentifikasi dan melaporkan potensi masalah dan pelanggaran keselamatan dan mengambil langkah segera untuk menyelesaikan masalah tersebut.

\section{Pastikan semua pekerja dilatih} dengan baik.

Organisasi harus memberikan pelatihan keselamatan kepada semua pekerja baik yang lama maupun yang baru dengan menggunakan bahasa yang mudah dipahami serta menggunakan alat papan pesan elektronik.

3. Pastikan pekerja memiliki peralatan yang tepat.

Pastikan pekerja memiliki dan menggunakan peralatan yang aman serta merawat peralatan tersebut dengan 
benar. Papan digital di tempat kerja dapat digunakan sebagai alat yang efektif untuk memperkuat pencegahan cedera.

\section{Berikan bantuan dan pesan keamanan visual.}

Gunakan kode warna, poster, label, dan / atau tanda untuk memperingatkan pekerja tentang potensi bahaya. Selain itu, letakkan poster K3 di semua area kerja dan gunakan informasi digital untuk menyiarkan informasi, pembaruan, dan pesan keselamatan yang penting. Misalnya, pengusaha dapat menampilkan catatan keselamatan mereka menggunakan penghitung otomatis. Bantuan visual ini akan menampilkan data waktu nyata dan mengingatkan pekerja untuk tetap aman.

5. Buat komite keselamatan dan adakan pertemuan keselamatan bulanan.

Adakan pertemuan sebulan sekali atau tiga bulan sekali untuk meminta umpan balik dari pekerja karena sangat membantu para manajer tentang potensi bahaya yang mungkin dialami para pekerja dan manajer mengetahui bagaimana perasaan pekerja, dan pekerja merasa dihargai, yang dapat meningkatkan kesehatan mental dan produktivitas

\section{Jadikan keselamatan menyenangkan. \\ Keselamatan kerja harus} dijadikan suatu budaya dan dilakukan dengan kesadaran yang tinggi dan menyenangkan. Papan digital juga dapat digunakan untuk membuat permainan, kuis, dan video bertema keselamatan.

\section{KESIMPULAN}

Keselamatan DNA dapat dikategorikan sebagai katalis yang kuat untuk meningkatkan kinerja individu dan mendewasakan budaya keselamatan organisasi. Termasuk dengan komitmen enam cara untuk memastikan tempat kerja yang aman dan mempromosikan budaya keselamatan yang kuat yaitu menghilangkan potensi bahaya, memastikan semua pekerja dilatih dengan baik, memastikan pekerja memiliki peralatan yang tepat, memberikan bantuan \& pesan keamanan visual, adanya komite keselamatan \& adakan pertemuan keselamatan bulanan, serta menjadikan keselamatan sesuatu yang menyenangkan.

\section{UCAPAN TERIMAKASIH}

Kami mengucapkan terimakasih kepada bapak Drs. W. Prasuad yang telah banyak memberi masukan dalam penyempurnaan makalah ini serta kepada KPTF PRSG yang telah mengizinkan makalah ini untuk diterbitkan di BPRN-Buletin Reaktor.

\section{REFERENSI}

[1] Kementrian tenaga kerja, Permenaker No. 05 tahun 1996 tentang sistem manajemen K3 (SMK3). Indonesia, 1996.

[2] International Organization for Standardization, "ISO 31000:2009 Risk management - Principles and guidelines," 2009.

[3] E. Tristan, "Safety DNA: The Key to Reducing Employee Exposure and Selecting," https://www.google.com/search? "Safety+DNA," vol. Diakses ta.

[4] "The Dupont Integrated Approach (DnA) for Safety: A Catalyst to Accelerate Performance," http://www.dupont.co.kr/content/d am/assets/

DNA_Global_Brochure_APAC, vol. Diakses ta.

[5] E. Sihombing, W. Prasuad, and Y. E. Yulianto, "Rancangan 
Kuisioner Safety DNA sebagai Alat Ukur Pengujian Sumber Daya Manusia PLTN Pertama di Indonesia," Senopaten, vol. ISBN: 978-, 2020.

[6] A. Cheyne, J. Tomas, S. Cox, and A. Oliver, "Modelling employee attitudes to safety: A comparison across sectors," Eur. Psychol., vol. Vol 4(1), 1999.

[7] A. Cheyne, S. Cox, A. Oliver, and J. Tomas, "Modelling safety climate in the prediction of levels of safety activity," Work Stress, vol. Vol 12(3), 1998.

[8] J. Ridley, Kesehatan dan Keselamatan Kerja, Edisi ke-3. Erlangga, 2008.

[9] J. S. Chokkar, "Safety at the workplace: A behavioural approach," Int. Labour, vol. Vol. 26, N, 1987.

[10] J. Roughton, "Developing on Effective Safety Culture: A Leadership Approach," USA Butterworth Heinnemann, 2002.

[11] Y. Handayani, "Pengaruh Penerapan Program Behavior Based Safety terhadap Penurunan Jumlah Tenaga Kerja di PT Denso Indonesia," 2011.

[12] Kemenakertrans, "Tekan Kecelakaan Kerja, Menakertrans Sebar 13.751 orang Ahli Keselamatan Kerja," 2012.

[13] H. W. Heinrich, Heinrich's Domino
Theory. 1959.

[14] A. Muflihah Darwis, N. Poniharwani, and A. Wira Lisrianti, "Kejadian kecelakaan kerja di industri percetakan kota Makassar," JKMM, vol. Vol. 3, No, 2020.

[15] P. Agbenorku, K. Aboah, and J. Akpaloo, "Epidemiological studies of burn patients in a burn center in Ghana: any clues for prevention?," Oxford Univ. Press, 2016.

[16] DuPont, Not Walking the Talk: DuPont's Untold Safety Failures. 2005. 